\title{
Current Status, Threats and Conservation Needs of The Endemic Cycas wadei Merrill
}

\section{Marler TE1 ${ }^{*}$ and Ferreras UF²}

${ }^{1}$ Western Pacific Tropical Research Center, College of Natural and Applied Sciences, University of Guam, UOG Station, Mangilao, Guam 96923

${ }^{2}$ Philippine Native Plants Conservation Society Inc, Ninoy Aquino Parks and Wildlife Center, Quezon City, Philippines

\begin{abstract}
The population size and structure of Cycas wadei were assessed along with habitat traits to update the current level of knowledge for conserving this Critically Endangered endemic species. Direct measurements of plant density and size, chemical analyses of soil and leaf tissue samples, and surveys of sympatric plants were conducted. The adult population was calculated at 5,051, indicating historical population size estimates were inaccurately low. Highest densities in forested fragments were 800 plants per hectare, with adults comprising $34 \%$ of the population. Density in grasslands was as high as 1,100 plants per hectare, with adults comprising $31 \%$ of the population. The dominant grass was Themeda gigantea (Cav.) Hackel, not Imperata as previously reported. The prediction that the soils were ultramafic was rejected but opinions that the soils were extremely infertile were confirmed by soil analyses. Leaf stoichiometry revealed the cycad plants were primarily limited by potassium availability and secondarily limited by phosphorus availability. Habitat conversion is the acute threat that must be monitored in the near future, and an attempt to moderate or halt this conversion is the greatest conservation need. Poaching is a second threat that has not been acute to date, but has the potential to become a greater threat if the remote habitat becomes more connected to national trade routes. Fire damage is the third major threat, and has the potential to become a greater threat if historical fire frequency is altered
\end{abstract}

Keywords: Culion Island; Cycad; Habitat characterization; Philippines; Population density; Risk assessment; Soil and leaf nutrient regimes

\section{Introduction}

Cycas wadei is Red-Listed as Critically Endangered [1]. This wellknown cycad species is one of the endemic Asian Cycas species that resides in a single population with a limited range. The species was listed as Endangered in 1998, Data Deficient in 2003, then Critically Endangered in 2010. It is also included in the DAO 2007-1 or the National List of Threatened Philippine Plants and their Categories falling under the Endangered A1cd, B2bc threat category [2]. To our knowledge, no empirical studies have been accomplished to establish the foundation of information available to validate the conservation status or needs.

A C. wadei status update would benefit from a quantitative framework for the first time. Our objectives were to conduct direct habitat observations and measurements to update the population status and increase our understanding of the habitat traits that may affect future conservation efforts.

\section{Material and Methods}

\section{Study site}

The endemic range of $C$. wadei is located in the central portion of Culion Island at ca. $50 \mathrm{~m}$ above sea level (Figure 1). The climate regime in this vicinity falls under Type I in the Modified CORONAS classification system as adopted by the Philippine Atmospheric and Geophysical and Astronomical Services Administration characterized by a pronounced dry season from November to May and a wet season that starts from June and extends up to October. On average, it receives an annual precipitation of 2,794 $\mathrm{mm}$ with the heaviest rainfall occurring during the months of July and August [3].

The population was mostly located within grasslands (Figure 2a), but extended into fragmented forested areas contiguous with the grasslands. Interviews with several local residents were conducted the first week of April 2014 and one site visit overseen by a local resident was accomplished 3 April 2014. The sympatric vegetation was identified and a list of the most common species was tallied.

No detailed geological studies or maps of Culion Island are currently available. An initial sampling was conducted in 1947 in Iraw and Pichiwan in the Northwestern part of Culion Island and in the 1960s in a small area in the southeast of Culion Island. The reports indicated that in some parts of the Island, the underlying rocks are composed of a bedded sequence of siliceous rocks of chert and quartzite [4], similar with those that occur in Busuanga Island [5]. A more recent exploratory study characterized Culion Island as having the rock facies of chert and that the manganese deposits were associated with the Liminangcong Formation [6]. This formation is designated to be anywhere in between Late Permian to Late Jurassic age based on its stratigraphic position and deductions from radiolarians, foraminifera, megalodonts, and conodonts [7].

The hills immediately adjacent to the C. wadei endemic habitat contained stands of Xanthostemon speciosus Merr., a tree often associated with chert outcrops in Culion and Busuanga Islands and ultramafic rocks in Southern Palawan Island. In the absence of a detailed geologic map, we cannot determine if the C. wadei habitat falls under this Formation.

*Corresponding author: Marler TE, Western Pacific Tropical Research Center, College of Natural and Applied Sciences, University of Guam, Mangilao, Guam 96923, USA, Tel: 16717352100; E-mail: thomas.marler@gmail.com

Received July 24, 2017; Accepted August 22, 2017; Published August 27, 2017

Citation: Marler TE, Ferreras UF (2017) Current Status, Threats and Conservation Needs of The Endemic Cycas wadei Merrill. J Biodivers Endanger Species 5: 193 doi: 10.4172/2332-2543.1000193

Copyright: @ 2017 Marler TE, et al. This is an open-access article distributed unde the terms of the Creative Commons Attribution License, which permits unrestricted use, distribution, and reproduction in any medium, provided the original author and source are credited. 
Citation: Marler TE, Ferreras UF (2017) Current Status, Threats and Conservation Needs of The Endemic Cycas wadei Merrill. J Biodivers Endanger Species 5: 193. doi: 10.4172/2332-2543.1000193

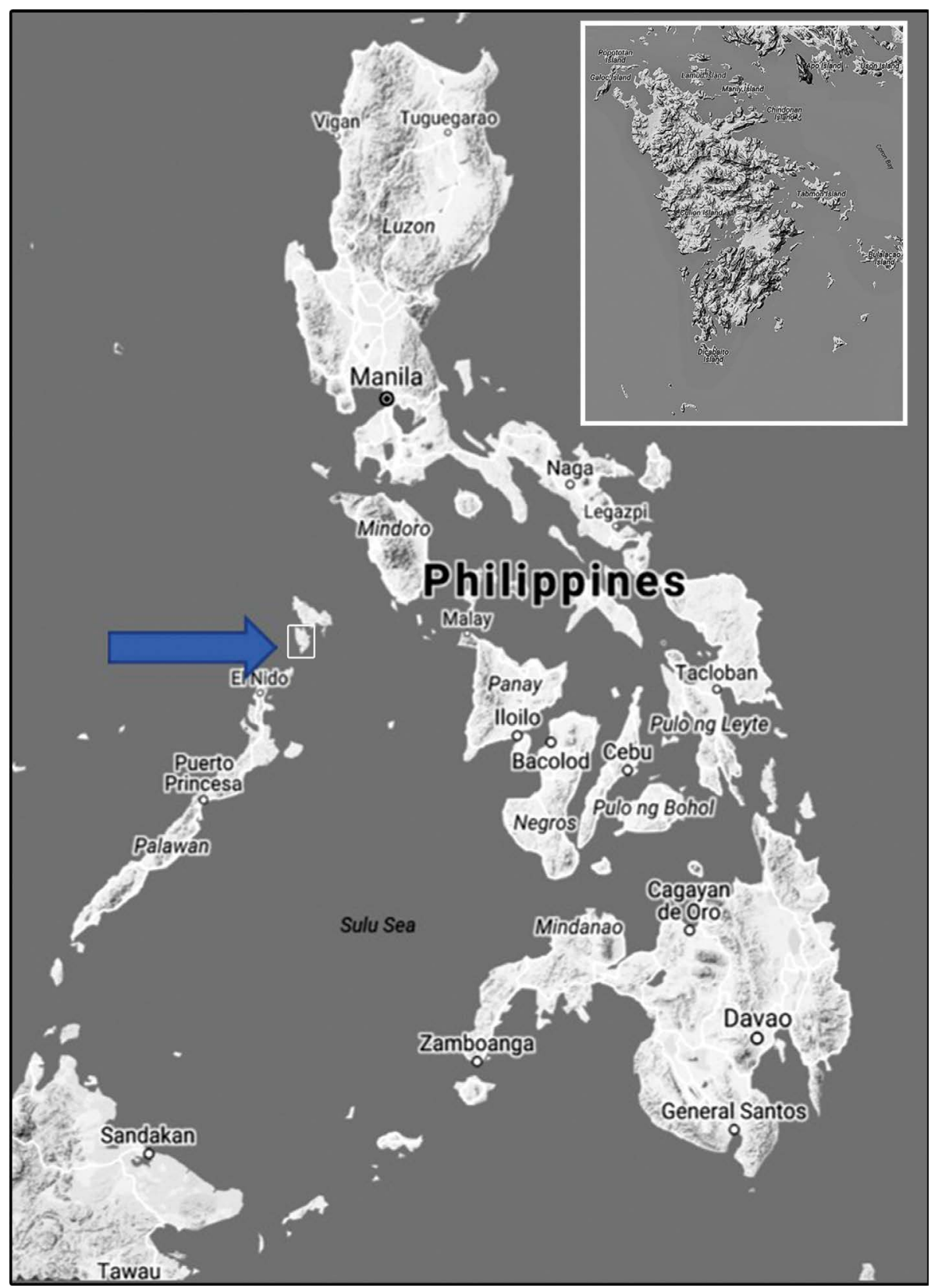

Figure 1: Map of the Philippine Island Archipelago with location of Culion Island depicted by blue arrow. Culion Island is shown in the insert.

\section{Population measurements}

Direct observations were made within the endemic limits of the species. We delineated 13 areas of occupancy based on vegetation cover type and cycad plant density. These were contiguous areas of occupancy and prescribed only for estimating population size. Six of these areas were low density, and we conducted direct counts of mature individuals within these areas. Population size within each of the seven high density areas of occupancy was estimated following establishment of three 10 $\mathrm{m} \times 10 \mathrm{~m}$ plots within each area. Height and observable sex of each individual plant within the plots were measured and recorded.

The density data within each of the $100 \mathrm{~m}^{2}$ plots was used to calculate the estimated total plant number within each of the high- density occupancy sites. We set $50 \mathrm{~cm}$ stem height as the lower limit for designating each tree as mature, as this was the shortest tree that presented evidence of reproductive structures. Although this protocol was not arbitrary, maturity of trees with shorter stems may be validated with more site visits, so our mature tree estimation may be a slight under-estimation. These plots included seedling counts, defined as plants with three or less leaves and no observable height growth of the stems. All plants that were larger than seedlings but less than $50 \mathrm{~cm}$ stem height were designated as juvenile.

Plant allometry was determined by measuring height and basal stem diameter of every tree along three $4 \mathrm{~m} \times 100 \mathrm{~m}$ transects. Each transect was positioned to begin in a grassland site, pass through a forest fragment, and exit into a grassland site. The length of the forested 
Citation: Marler TE, Ferreras UF (2017) Current Status, Threats and Conservation Needs of The Endemic Cycas wadei Merrill. J Biodivers Endanger Species 5: 193. doi: 10.4172/2332-2543.1000193

transect section was approximately $50 \mathrm{~m}$, and the length of each peripheral grassland transect section was approximately $25 \mathrm{~m}$. These methods ensured an unbiased population of measured trees within both habitat types, and avoided the $C$. wadei trees that extended a few meters into the peripheral forested areas. Each tree was designated as shaded understory or open grassland. The relationship between stem height and basal diameter was determined for each habitat type to generate one linear regression model for each transect. Differences in allometry between the two habitat types were determined by paired $\mathrm{t}$-test of the linear slopes, $\mathrm{n}=3$.

\section{Tissue and soil sampling}

We initiated a transect in the southwest area of the endemic range and followed a path of approximately $40^{\circ}$ bearing in order to span the entire endemic range. We purchased leaf and soil samples from our local host by designating six sampling sites at approximately equal distances along the transect. Mature green leaflets and senesced leaflets from attached dead leaves were collected from at least 10 individuals at each sampling site. Height of the sampled trees was $1.5 \mathrm{~m}$ to $2.5 \mathrm{~m}$. A soil subsample from the $0-15 \mathrm{~cm}$ depth was collected 2-m away from each of the sampled trees and in each of the four cardinal directions. All soil samples were combined into one homogenized sample for each site. Therefore, chemical analyses were enabled for six samples of green leaf tissue, senesced leaf litter tissue, and soils, with each leaf sample supported by at least 10 subsamples and each soil sample supported by at least 40 subsamples.

Soil samples were dried at $50^{\circ} \mathrm{C}$. Total carbon (C) and nitrogen (N) were determined by dry combustion [8] using a FLASH EA1112 CHN analyzer (Thermo Fisher, Waltham, Mass., USA). Phosphorus (P) was extracted using Olsen's method [9], other macronutrients and micronutrients were extracted by diethylenetriaminepentaacetic acid [10], and metals were determined by nitric acid digestion [11]. Contents were determined by inductively coupled plasma optical emission spectrometry [12] with a Spectro Genesis analyzer (SPECTRO Analytical Instruments, Kleve, Germany).

Leaflet tissue samples were stored in ambient conditions until they were prepared for analysis. Tissue was dried at $70^{\circ} \mathrm{C}$ then milled to pass through a 1-mm screen. Lignin was quantified with the acetyl-bromide method [13]. Total C, total N, and metals were determined as described for soils. Macronutrients and micronutrients were determined by standard digestion and inductively coupled plasma optical emission spectrometry methods.

A paired t-test was employed to determine the differences in element concentrations between mature green leaves and senesced leaf litter. Nutrient retranslocation efficiency was calculated as the change in element concentration between green and senesced leaves divided by the concentration in green leaves, and represented a measure of the
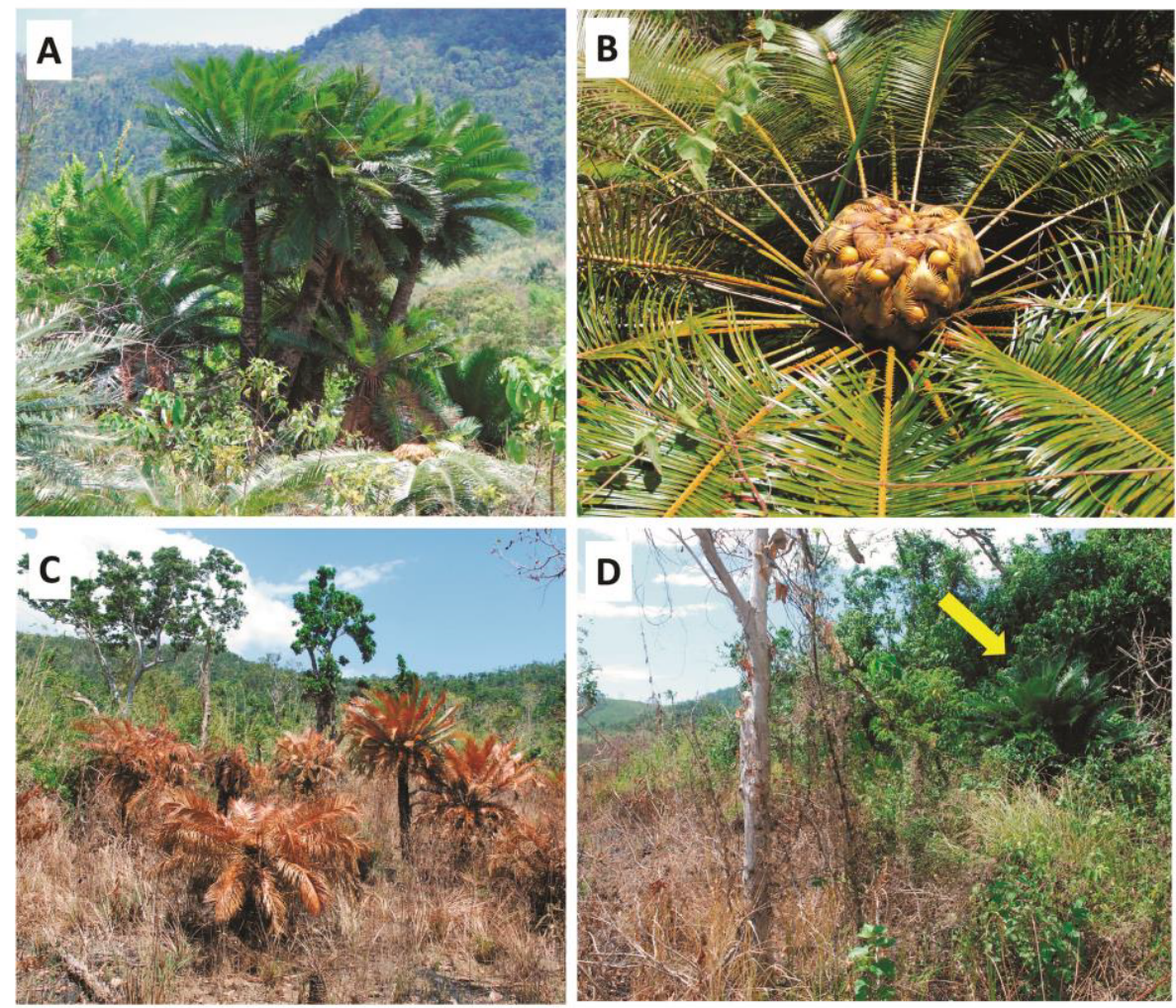

Figure 2: Cycas wadei habitat. (A) Representative plants within the grassland sites. (B) Female reproductive structure revealing naked seeds borne on sporophylls. (C) Damage to cycad plants during grassland fires. (D) Cycad plant (yellow arrow) protected by the forest edge revealing no damage from a recent adjacent grassland fire. 
percentage of the nutrients that were withdrawn prior to abscission. Stoichiometry traits were calculated as the quotients $\mathrm{C} / \mathrm{N}, \mathrm{C} / \mathrm{P}, \mathrm{C} /$ potassium (K), N/P, N/K, and K/P. Stoichiometry quotients were logtransformed prior to analysis by paired $\mathrm{t}$-test.

\section{Results}

\section{Cycad census}

Our direct calculations estimated population size as 5,051 mature individuals. To our knowledge, this direct count is the first-ever empirical approach employed to determine the C. wadei population size. Recent conversion of habitat for construction of dwellings, planting of a burgeoning rubber plantation, construction of a rubber processing facility, and construction of a road network to connect these activities has destroyed large expanses within the endemic range. Therefore, past reports that population size was 5,000 mature individuals [1] obtained prior to this recent habitat conversion were inaccurately low. The current population trend is decreasing due to the loss of habitat.

The highest densities within forested fragments typically ranged from $700-800$ plants per hectare, with $34 \%$ adults, $2 \%$ juvenile, and $64 \%$ seedlings. Highest density within grasslands typically ranged from 1,000-1,100 plants per hectare, with $31 \%$ adults, $26 \%$ juvenile, and $43 \%$ seedling. The high percentage of seedlings and numerous healthy seed-producing female plants (Figure $2 \mathrm{~b}$ ) validated a relatively healthy population with considerable recruitment potential. Within the grasslands, $58 \%$ of the plants exhibiting adult stature could be directly sexed, with a 1:1.5 male: female relationship. In contrast, within the forest fragments only $27 \%$ of the plants exhibiting adult stature could be sexed and $100 \%$ of these were female.

The trees within shaded forest fragments exhibited a smaller stem diameter per unit stem height increment than the trees within grasslands (Figure 3). This led to an allometric slope for the grassland tress that was $83 \%$ of that for the forest trees $(\mathrm{P}=0.0009)$.

\section{Habitat vegetation}

The areas of occupancy exhibited minimal slope, and the dominant vegetation was a fire disclimax community with the ground cover

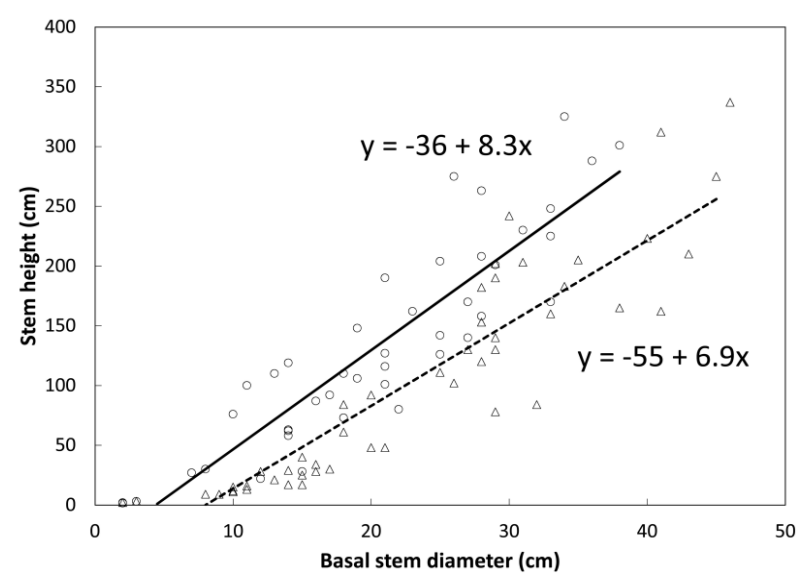

Figure 3: The relationship between Cycas wadei stem height and basa diameter for forested (circles, solid line) and grassland (tringle, dashed line) sites. dominated by Themeda gigantea (Cav.) Hackel. This is a perennial grass commonly associated with pyrogenous grasslands or what is commonly known as "parang" vegetation in the Philippines. Past reports $[1,14]$ that Imperata cylindrica (L.) P. Beauv. comprised the dominant grass were inaccurate. Among the trees present in the forest fragments were Antidesma ghaesembilla Gaertn., Cratoxylum formosum (Jack) Dyer, Pittosporum moluccanum (Lam.) Miq., Alstonia macrophylla Wall. ex G. Don., Sterculia foetida L., Mallotus philippensis (Lam.) Muell-Arg., Dillenia monantha Merr., Guioa sp., Syzygium, Gardenia sp., Vitex sp., Semecarpus cuneiformis Blanco, Ardisia sp., Canarium asperum Benth, and Mangifera altissima Blanco. These angiosperm trees were widely dispersed and often occurred as scattered individuals, less often as closed canopies that filter the sun for the cycads underneath. The tallest trees in the forest fragments exhibited heights of 5-6 meters. Small to medium sized shrubs found growing interspersed with the cycads included Micromelum minutum (G. Forst.) Wight \& Arn., Antidesma montanum Blume, Pavetta phanerophlebia Merr., Wendlandia luzoniensis DC var. luzoniensis, Melastoma culionense Merr., Grewia sp., Helicteres hirsuta Lour., Callicarpa sp., Sauropus sp., Mussaenda sp., and Tabernaemontana sp. The rattans belonging to the genus Calamus and Daemonorops occurred in association with some trees. Vines that were common in the habitat were Jasminum, Tetracera, Smilax, Dioscorea, and Flagellaria indica L. Lianas in the fragmented forests were Entada.

\section{Soil and plant chemistry}

Our $0 \mathrm{~cm}$ to $15 \mathrm{~cm}$ soil samples exhibited a pH of 5.3 to 5.5 . The ranges in soil macronutrient and micronutrient concentrations were minimal, and were generally low to very low in relation to plant nutrition needs (Table 1). Additionally, none of the metals exhibited excessive quantities, especially the metals typically associated with Philippine ultramafic substrates (Table 1). Considering the $\mathrm{pH}$ of these soils, aluminum toxicity may be a limiting factor for vegetation health. We did not quantify available aluminum.

Most of the C. wadei leaf chemical traits differed between mature green leaves and senesced leaflitter (Tables 2 and 3). The metabolitelignin was greater in senesced leaves, but all nutrients that were significantly different were greater in green mature leaves. The ecologically important $\mathrm{C}$ and $\mathrm{N}$ concentrations were not different between the two leaf types. Four of the six measured metals differed between the two leaf types (Table 3). Arsenic and selenium concentrations increased as leaves senesced, evincing accretion of these metals. Cadmium and chromium concentrations were greater in mature green leaves, evincing retranslocation of these metals as leaves senesced.

The quotient $\mathrm{C} / \mathrm{N}$ was not different between green and senesced leaves (Table 4), which was predicted from the lack of significance for each of these individual elements (Table 2). In contrast, $\mathrm{C} / \mathrm{P}, \mathrm{C} / \mathrm{K}$, $\mathrm{N} / \mathrm{P}$, and $\mathrm{N} / \mathrm{K}$ were greatly increased in the senesced leaf tissue when compared with the green leaf tissue (Table 4). The quotient K/P was slightly decreased in senesced leaf tissue compared with green leaf tissue.

Several essential nutrients exhibited substantial retranslocation during leaf senescence. The retranslocation of $\mathrm{N}$ was only $6.3 \%$, but the other two macronutrients with substantially lower concentrations in senesced leaves exhibited retranslocation of 54.5\% (P) and 56.4\% (K). Four of the micronutrients exhibited substantial retranslocation: $48.4 \%$ for iron, $42.7 \%$ for zinc, $42.4 \%$ for boron, and $40.3 \%$ for nickel. 


\begin{tabular}{|c|c|c|c|c|c|c|}
\hline Macro-nutrients & Total carbon $\left(\mathbf{m g ~ g}^{-1}\right)$ & Total nitrogen $\left(\mathrm{mg} \mathrm{g}^{-1}\right)$ & Phosphorus ( $\mu \mathrm{g} \mathrm{g}^{-1}$ ) & Potassium ( $\left.\boldsymbol{\mu} \mathbf{g} \mathbf{g}^{-1}\right)$ & Calcium ( $\left.\mathbf{g g ~ g}^{-1}\right)$ & Magnesium $\left(\mu \mathrm{g} \mathrm{g}^{-1}\right)$ \\
\hline Range & $20.5-24.3$ & $1.11-1.32$ & $6.22-6.54$ & $101-120$ & $344-369$ & $171-193$ \\
\hline Micro-nutrients & Manganese $\left(\mu \mathbf{g ~ g}^{-1}\right)$ & Iron $\left(\mu \mathbf{g ~ g}^{-1}\right)$ & Copper $\left(\mu \mathbf{g ~ g}^{-1}\right)$ & Zinc $\left(\mu \mathbf{g ~ g}^{-1}\right)$ & Nickel $\left(\mu \mathbf{g ~ g}^{-1}\right)$ & \\
\hline Range & $50.2-71.5$ & $56.3-72.1$ & $9.19-9.42$ & $24.1-25.0$ & $2.41-2.53$ & \\
\hline Metals & Arsenic $\left(\mu \mathbf{g ~ g}^{-1}\right)$ & Cadmium $\left(\mu \mathrm{g} \mathrm{g}^{-1}\right)$ & Cobalt $\left(\mu g_{~ g^{-1}}\right)$ & Chromium ( $\left.\boldsymbol{\mu g ~ g}^{-1}\right)$ & Lead $\left(\mu g g^{-1}\right)$ & Selenium( $\left.\boldsymbol{\mu g} \mathbf{g ~ g}^{-1}\right)$ \\
\hline Range & $0.04-0.06$ & $0.02-0.03$ & $3.89-3.97$ & $36.8-37.9$ & $2.78-2.91$ & $0.08-0.10$ \\
\hline
\end{tabular}

Table 1: Concentration of macronutrients, micronutrients, and metals in the $0-15 \mathrm{~cm}$ surface layer of Cycas wadei habitat soils, $\mathrm{n}=6$

\begin{tabular}{|c|c|c|c|}
\hline Leaf Trait & Green Mature & Senesced litter & Significance \\
\hline Lignin $\left(\mathrm{mg} \mathrm{g}^{-1}\right)$ & 310 & 412 & $<0.0001$ \\
\hline Total carbon $\left(\mathrm{mg} \mathrm{g}^{-1}\right)$ & 508 & 513 & 0.4881 \\
\hline Total nitrogen $\left(\mathrm{mg} \mathrm{g}^{-1}\right)$ & 20.7 & 19.4 & 0.1798 \\
\hline Phosphorus $\left(\mathrm{mg} \mathrm{g}^{-1}\right)$ & 1.12 & 0.51 & $<0.0001$ \\
\hline Potassium $\left(\mathrm{mg} \mathrm{g}^{-1}\right)$ & 7.39 & 3.22 & $<0.0001$ \\
\hline Calcium $\left(\mathrm{mg} \mathrm{g}^{-1}\right)$ & 2.51 & 2.49 & 0.4428 \\
\hline Magnesium $\left(\mathrm{mg} \mathrm{g}^{-1}\right)$ & 1.43 & 1.32 & 0.1271 \\
\hline Manganese $\left(\mu \mathrm{g} \mathrm{g}^{-1}\right)$ & 152 & 141 & 0.1125 \\
\hline Iron $\left(\mu \mathrm{g} \mathrm{g}^{-1}\right)$ & 71.3 & 36.8 & $<0.0001$ \\
\hline Zinc $\left(\mu \mathrm{g} \mathrm{g}^{-1}\right)$ & 10.3 & 5.9 & $<0.0001$ \\
\hline Copper $\left(\mu \mathrm{g} \mathrm{g}^{-1}\right)$ & 3.91 & 3.33 & 0.0002 \\
\hline Boron $\left(\mu \mathrm{g} \mathrm{g}^{-1}\right)$ & 17.2 & 9.9 & $<0.0001$ \\
\hline Nickel $\left(\mu \mathrm{g} \mathrm{g}^{-1}\right)$ & 2.53 & 1.51 & $<0.0001$ \\
\hline
\end{tabular}

Table 2: Essential nutrients and lignin content in mature green leaves and desiccated litter from Cycas wadei trees. Significance determined by paired t-test, $n=6$.

\begin{tabular}{|c|c|c|c|}
\hline Leaf trait $\left(\boldsymbol{\mu g} \mathbf{~ g}^{-1}\right)$ & Green mature & Senesced Litter & Significance \\
\hline Arsenic & 0.02 & 0.09 & $<0.0001$ \\
\hline Cadmium & 0.13 & 0.09 & $<0.0001$ \\
\hline Cobalt & 0.08 & 0.06 & 0.1531 \\
\hline Chromium & 0.33 & 0.18 & $<0.0001$ \\
\hline Lead & 0.22 & 0.23 & 0.1244 \\
\hline Selenium & 0.41 & 0.48 & 0.0034 \\
\hline
\end{tabular}

Table 3: Concentration of metals in mature green leaves and desiccated litter from Cycas wadei trees. Significance determined by paired t-test, $\mathrm{n}=6$.

\begin{tabular}{|c|c|c|c|}
\hline Stoichiometry trait & Green mature & Senesced Litter & Significance \\
\hline C/N & 24.5 & 26.4 & 0.1612 \\
\hline C/P & 454 & 1006 & $<0.0001$ \\
\hline C/K & 68.7 & 159.3 & $<0.0001$ \\
\hline N/P & 18.5 & 37.9 & $<0.0001$ \\
\hline N/K & 2.80 & 6.02 & $<0.0001$ \\
\hline K/P & 6.61 & 6.31 & 0.0384 \\
\hline
\end{tabular}

Table 4: Stoichiometric relations of carbon $(C)$, nitrogen $(N)$, phosphorus $(P)$, and potassium $(\mathrm{K})$ in mature green leaves and senesced leaf litter of Cycas wadei. Significance determined by paired t-test on log-transformed data, $\mathrm{n}=6$.

\section{Discussion}

Our results and observations represent the first time that a quantitative approach has been employed to assess the conservation status of $C$. wadei. The results confirm the designation of Critically Endangered, verify the population is decreasing, and reveal that the major threats are all anthropogenic. Fortunately, the biotic threats from specialist insect herbivores that are endangering other Cycas species were not observed.

Some areas in the $C$. wade $i$ habitat have been very recently converted to Para Rubber Tree (Hevea brasiliensis (Humb., Bonpl. \& Kunth) Muell.Arg.) and teak (Tectona grandis L.f.) plantations. Both species are exotic to the Philippines with the former known for being a commercially

important tree for the latex which is used for the manufacture of rubber and the latter being economically important for quality timber. These trees were planted under a long-term lease by the developer within the C. wadei range. Undoubtedly, the expansion of this plantation is the greatest direct threat to conservation efforts. In addition, these activities may have a cascading impact on the ecology, reproduction, and biology of C. wadei in ways that result from population declines and fragmentation. The species could be downgraded to Endangered if this habitat conversion is halted.

The local residents have invested considerable effort into attempts to cultivate some of the common cash crops on the site. These attempts included sweet potato (Ipomoea batatas (L.) Lam.), corn (Zea mays L.), and rice (Oryza sativa L.). All attempts have failed, but this threat may persist into the future.

This cycad species is in demand as an ornamental plant. Poaching of large specimens occurs fairly often to satisfy demand for landscape specimens on Culion Island and for coastal resorts on nearby islands. We observed numerous recently excavated holes and one discarded large tree that was uprooted then inadvertently left by the roadside. Poaching is a minor threat at this time due to the logistical constraints of transporting live plants from the remote habitat. Poaching has the potential to become a greater threat if remote Culion Island becomes more connected to national trade routes. For example, the addition of airplane flights to the island would greatly increase the threat of poaching.

Purposeful setting of fires within the endemic range occurs frequently. The direct fire damage to $C$. wadei foliage and reproductive structures can be substantial (Figure 2c), but the historical frequency does not reveal evidence of compromised health of juvenile or mature trees. The plants within the forest fragments are more protected from the grassland fires (Figure 2d). Fire damage has the potential to become a greater threat if fire frequency is altered from historical frequency. More frequent events may diminish the potential for the resilient cycad plants to recover between the stress events. Less frequent events may increase the fuel load to levels that generate greater fire intensity during the burns, and this may cause increased direct plant damage.

Green leaf nutrient concentrations were low for C. wadei. The impoverished soils explain these results for most of the nutrients, but not for N. All cycads associate with endosymbionts that fix N [15], and therefore are not dependent on soil mineral resources to supply their $\mathrm{N}$ needs. Numerous studies have shown that stoichiometric relations among the macronutrients may be used to predict limitations in a habitat's nutrient budget [16-20]. Despite the relatively low $\mathrm{N}$, the $\mathrm{N} / \mathrm{P}$ of 18.5 exceeds the value of 14 which indicates that $C$. wade $i$ is more limited by $\mathrm{P}$ than by $\mathrm{N}$. The $\mathrm{N} / \mathrm{K}$ of 2.8 exceeds the value of 2.1 which indicates $C$. wadei is also more limited by $\mathrm{K}$ than by N. And the $\mathrm{K} / \mathrm{P}$ of 6.6 is lower than the value of 9.7 which indicates $C$. wadei is more limited by $\mathrm{K}$ than by $\mathrm{P}$. Confirmation of the $\mathrm{K}$ and $\mathrm{P}$ limitation that is revealed in the stoichiometric relationships could be tested by observing plant response to $\mathrm{K}$ and $\mathrm{P}$ additions to the soils. 
Plants withdraw about $50 \%$ of leaf $\mathrm{N}$ and $\mathrm{P}$ prior to leaf abscission $[21,22]$, and withdraw about $70 \%$ of the leaf $\mathrm{K}$ prior to leaf abscission [23]. The average $\mathrm{N}$ retranslocation efficiency for C. wadei was $6.3 \%$, which is exceedingly low compared to the global average. Our average $\mathrm{P}$ retranslocation efficiency of $54.5 \%$ was in line with the global database. Our K retranslocation efficiency of $56.4 \%$ was considerably lower than global values. Only one other report that we are aware of included nutrient retranslocation dynamics of a cycad species [24]. In this study, the green leaf tissue N, P, and K contents of Cycas nitida K.D. Hill \& A. Lindström exceeded those of C. wadei. Retranslocation of C. nitida nutrients also greatly exceeded the retranslocation we report for C. wadei. In addition to the $\mathrm{N}, \mathrm{P}$, and $\mathrm{K}$ traits, the retranslocation of many nutrients (Table 2) and metals (Table 3) can be calculated from our data for C. wadei. To our knowledge, this is first report for any cycad species that includes retranslocation percentages for so many essential nutrients.

The concentrations of various elements and secondary metabolites in senesced leaf litter exerts strong influence over decomposition rates and nutrient turnover dynamics [25,26]. Greater relative contents of carbon and lignin, for example, decrease decomposition rates. In contrast, greater relative contents of nutrients increase decomposition rates. Because retranslocation percentages of nutrients by $C$. nitida [24] exceeded those of $C$. wadei, the carbon:nutrient stoichiometry traits of senesced leaves (Table 4) were more similar to those of $C$. nitida than for green leaves. Chemical traits of senesced leaf litter have also been reported for Cycas micronesica K.D. Hill [27]. A comparison of C. wadei and $C$. micronesica litter stoichiometry reveals idiosyncratic results. The $\mathrm{C} / \mathrm{N}$ and $\mathrm{C} / \mathrm{K}$ of $C$. wadei litter (Table 4) were lower than those of $C$. micronesica, but the $\mathrm{C} / \mathrm{P}$ of $\mathrm{C}$. wadei was double that of $\mathrm{C}$. micronesica. The relationships involving lignin also revealed no discernable pattern. Cycas wadei litter lignin:N of 21.2 (Table 2) was slightly greater than that of C. micronesica. Cycas wadei litter lignin:K of 128 was slightly less than that of C. micronesica. But C. wadei litter lignin: $\mathrm{P}$ of 808 was triple that of C. micronesica. Clearly, building a large database of cycad species litter traits is needed to enable a better understanding of how cycads as a group influence the biogeochemistry of their respective habitats.

The thinner stems of the $C$. wadei trees within the forest fragments (Figure 2) may be caused by the disparity in sun exposure between the two habitat types. Thinner stems in shaded conditions are common among arborescent spermatophytes. However, the repeated fire stress in the grassland trees and the absence of this stress in the forest fragment trees may also be a causal factor. The pachycaulous stems of cycads are unique in construction, and exhibit a persistent parenchymatous cortex that combines with the bark to provide a peripheral ring around the youngest vascular cylinders [28]. The height:diameter relationship of the short-statured plants exhibited greater difference between the two habitat types than for the taller plants (Figure 3). For example, the predicted height for a grassland plant with a $35-\mathrm{cm}$ diameter stem was $73 \%$ of that for a forest plant. But the predicted height for a grassland plant with a $10-\mathrm{cm}$ diameter stem was only $30 \%$ of that for a forest plant. These robust stems in the grassland juvenile plants may be the consequence of an adaptive mechanism to tolerate the frequent grassland fires. The level of plasticity in stem cortex width is not known, but destructive experimental approaches with less threatened arborescent Cycas taxa could determine if chronic exposure to fires can elicit a wider cortex layer as an adaptive approach for protecting the cycad stem's vascular system.

During this single visit, $41 \%$ of the trees with adult stature could be sexed, and there was one male for every 2.8 female trees observed.
This sort of deviation from 1:1 is common with single visits to cycad populations and offers little help toward identifying the true male and female counts. The outcome of this snapshot metric is dependent on the window of time since the most frequent reproductive event for each mature tree. Evidence of in situ Cycas male reproductive structures disappears rapidly because the pollinators quickly consume the reproductive tissue [29]. But evidence of female reproductive structures persists for years with some Cycas species. Therefore, our bias toward more female trees is not surprising for a singular habitat visit.

Our observations that habitat type exerted a profound effect on the male:female relationship has not been previously reported for any cycad species to our knowledge. Indeed, this April 2014 visit revealed no signs of any male trees within the shaded forest communities, but signs of many male trees within the grasslands. We suggest this outcome has no bearing on the absolute number of male trees, but instead is simply evidence that none of the many male trees in the forest fragments developed cones during the few months prior to our visit. Numerous site visits throughout an annual cycle may reveal some months where a more even male:female quotient occurs and some months where the forest male plants develop more cones than the grassland male plants. One testable hypothesis that may explain these results is that fires stimulate coning of $C$. wadei male plants, and the absence of signs of recent male cones in the shaded forest plants may be a consequence of the absence of recent fire damage. Stimulation of coning in Encephalartos and Macrozamia has been reported [30,31]. A second testable hypothesis that may explain the lack of observed male trees in the forested sites is that the mature plants simply produce cones less often due to the shade. Monthly site visits that compare coning frequency of shaded versus grassland trees would answer this question. Our report of how habitat type may exert a strong influence on cycad reproductive phenology deserves further study, especially for indigenous cycad species that can be found in numerous ecological niches.

The discontinuous size-class structures in the forested sites also deserves further study. Demographic results like this usually indicate regenerative stress. This species may require high light conditions for seedling persistence, such that the annual pulse of seedling germinations in the shaded conditions are phased out through attrition prior to graduating to the juvenile size category.

\section{Conservation needs}

All political, legal, and public relations approaches available should be devoted toward stopping the habitat conversion. Unlike insidious biological threats that would require site visits, this threat can be quantified over time without repeated site visits by anyone with access to high quality satellite imagery.

Identify the beetle pollinator species associated with $C$. wadei. Cycas species are associated with mutualist pollinator species that exploit the male cones for recruitment [32-34]. These C. wadei pollinator populations will be placed under greater threats as the $C$. wadei population declines or becomes fragmented. This development carries a greater risk to Philippine biodiversity if the $C$. wadei pollinator is a unique, endemic pollinator. In this case, the currently unidentified taxon is already critically endangered along with its mutualist host. While these small animals may not be robust and charismatic like the cycad, if threats to their survival are anthropogenic, then they deserve an anthropogenic conservation solution. Moreover, as population size of either mutualist continues to decline, the mutualism itself may begin 
to collapse and become more endangered than the population of either organism.

Establish off-site germplasm collection with well-documented sub-populations. The success of off-site conservation collections is dependent on adequate genetic capture of the in situ populations. The development of molecular tools to inform conservation decisions has improved our understanding of tropical plant conservation in off-site collections $[35,36]$. Collection of propagules over several years and collection from peripheral subdivided regions of the areas of occupancy improve the successes of genetic capture. The genetic landscape of other insular Cycas species has been shown to be highly structured [37], with minimal mixing among different locations. Therefore, the $C$. wadei plants located in the various peripheral subpopulations may be distinct, and should be represented during establishment of an off-site collection. The C. wadei sub-population located in the SE periphery of the endemic range has already been killed during habitat conversion, so conservation of that portion of the genetic diversity is no longer achievable. The establishment of an off-site germplasm collection should be accomplished before more sub-populations are lost.

\section{Summation}

We believe our multi-faceted approach for updating the status of $C$. wadei may be used as a model for other threatened taxa assessments and updates. Updates based on cursory anecdotal observations may provide a fairly accurate census, but understanding the underlying threats and potential for future conservation successes may be constrained by this cursory approach. Our methods addressed population demography, nutrient budgets, habitat type, and sympatric species to provide a comprehensive overview of the $C$. wadei population status. For example, the threat of conversion for agriculture within the $C$. wadei habitats remains real. The past attempts have failed, but the reasons for these failures were not known. Since swidden agriculture protocols of the Philippine tribal communities are supported by thousands of years of traditional knowledge, the possibility that the agriculturists did not know what they were doing is not a reasonable explanation. We are left with limitations of the soils as causal agents. These limitations may be nutrient deficiencies due to impoverished soils as the local residents opined, or they may be metal toxicities due to ultramafic conditions as evidenced by the presence of indicator tree species in the forests surrounding the cycad habitat. Mitigating the former limitation is achievable using international agricultural approach of adding commercial fertilizer. Identification of a cash crop with a market value that would pay for the fertilizer inputs would remove the constraints on this threat, then wholesale conversion of the cycad habitat to agriculture use may ensue. Mitigating the latter limitation is less easily achieved, as large volumes of amendments would be required to address the metal toxicities. Our choice to include soil analyses in our methods confirmed that these moderately acid soils simply lack nutrition (Table 1). Therefore, future conservation approaches cannot ignore that the threat of conversion to agronomic or horticultural crop production remains high. We suggest that future status updates based on site visits to other endangered cycad species populations should be conducted with a similar multi-faceted approach using protocols that are tailored to the unanswered questions to more fully enable evidence-based conservation decisions. The Critically Endangered status of C. wadei is confirmed, but could be downgraded to Endangered in the future if habitat conversion is stopped.

\section{Acknowledgements}

This material is based upon work that is supported by the National Institute of Food and Agriculture, United States Department of Agriculture, under award number 2013-31100-06057.

\section{References}

1. Hill KD (2010) Cycas wadei. The IUCN Red List of Threatened Species 2010 e.T42097A10631294.

2. Fernando ES, Co LL, Lagunzad DA, Gruezo WS, Barcelona JF, et al. (2008) Asia Life Sciences S3: 1-52.

3. PAGASA-IRI-LDEO Climate Library (2017) Philippines.

4. Ibaňez CB (1960) Geologic Investigation of the Manganese Deposits of Binabaan, Culion Island. Palawan. Bureau of Mines p: 9.

5. Lim NN, Gabatero NC (1947) The Iraw and Pichiwan Manganese Prospects in the Island of Culion, Palawan. Bureau of Mines p: 7

6. Japan International Cooperation Agency (1988) Report on the Minera Exploration: Mineral Deposits and Tectonics of Two Contrasting Geologic Environments in the Republic of the Philippines (Phase IV-Part 1) Palawan. Metal Mining Agency of Japan, Japan.

7. Mines and Geosciences Bureau (2010) Geology of the Philippines (2 ${ }^{\text {nd }}$ Edn.) Department of Environment and Natural Resources p: 532.

8. Nelson DW, Sommers LE (1996) Total carbon, organic carbon, and organic matter. p. 961-1010. In: Sparks DL (editor) Methods of soil analysis. Part 3 Chemical methods. SSSA Book Series No. 5. SSSA and ASA: Madison, WI.

9. Olsen SR, Cole CV, Watanabe FS, Dean LA (1954) Estimation of available phosphorus in soils by extraction with sodium bicarbonate. United States Department of Agriculture Circ pp: 939.

10. Berghage RD, Krauskopf DM, Warncke DD, Widders I (1987) Micronutrient testing of plant growth media extractant, identification and evaluation. Commun Soil Sci Plant Anal 18: 1089-1109.

11. United States Environmental Protection Agency (1992) EPA Method 3005 USEPA, Cincinnati, Ohio.

12. Hou X, Jones BT (2000) Inductively Coupled Plasma/Optical Emission Spectrometry. In: Meyers RA (editor), Encyclopedia of Analytical Chemistry John Wiley \& Sons: Chichester p: 9468-9485.

13. liyama K, Wallis AFA (1990) Determination of lignin in herbaceous plants by an improved acetyl bromide procedure. J Sci Food Agric 51: 145-161.

14. Lindström AJ, Hill KD, Stanberg LC (2008) The genus Cycas (Cycadaceae) in the Philippines. Telopea 12: 119-145.

15. Norstog KJ, Nicholls TJ (1997) The biology of the cycads. Cornell University Press: Ithaca.

16. Aerts R, Chapin FS (2000) The mineral nutrition of wild plants revisited: a reevaluation of processes and patterns. Adv Ecol Res 30: 1-67.

17. Güsewell S (2004) N: P ratios in terrestrial plants: variation and functional significance. New Phytologist 164: 243-266.

18. Koerselman W, Meuleman AFM (1996) The vegetation N: P ratio: a new tool to detect the nature of nutrient limitation. J Applied Ecol 33: 1441-1450.

19. Venterink OH, Wassen MJ, Verkroost AWM, de Ruiter PC (2003) Species richness-productivity patterns differ between $\mathrm{N}$-, $\mathrm{P}$-, and $\mathrm{K}$-limited wetlands. Ecology 84: 2191-2199.

20. Tessier JT, Raynal DJ (2003) Use of nitrogen to phosphorus ratios in plant tissue as an indicator of nutrient limitation and nitrogen saturation. J Appl Ecol 40: 523-534

21. Aerts $R$ (1996) Nutrient resorption from senescing leaves of perennials: are there general patterns? J Ecol 84: 597-608.

22. Killingbeck KT (1996) Nutrients in senesced leaves: keys to the search for potential resorption and resorption proficiency. Ecology 77: 1716-1727.

23. Vergutz L, Manzoni S, Porporato A, Novais RF, Jackson RB (2012) Global resorption efficiencies and concentrations of carbon and nutrients in leaves of terrestrial plants. Ecological Monographs 82: 205-220.

24. Marler TE, Ferreras UF (2015) Disruption of leaf nutrient remobilization in coastal Cycas trees by tropical cyclone damage. J Geogr Nat Disast 5: 1-7. 
Citation: Marler TE, Ferreras UF (2017) Current Status, Threats and Conservation Needs of The Endemic Cycas wadei Merrill. J Biodivers Endanger Species 5: 193. doi: 10.4172/2332-2543.1000193

Page 8 of 8

25. Aerts R (1997) Climate, leaf litter chemistry and leaf litter decomposition in terrestrial ecosystems: a triangular relationship. Oikos 79: 439-449.

26. Cornwell WK, Cornelissen JHC, Amatangelo K, Dorrepaal E, Eviner VT, et al. (2008) Plant species traits are the predominant control on litter decomposition rates within biomes worldwide. Ecology letters 11: 1065-1071.

27. Marler TE, Dongol, N (2016) Three invasive insects alter Cycas micronesica leaf chemistry and predict changes in biogeochemical cycling. Communicative \& Integrative Biology 9: e1208324.

28. Marler TE, Lindström A, Fisher JB (2010) Stem tissue dimensions correlate with vulnerability to injury for six Cycas species. HortScience 45: 1293-1296.

29. Marler TE (2010) Cycad mutualist offers more than pollen transport. Amer J Botany 97: 841-845.

30. Cousins SR, Witkowski (2017) African cycad ecology, ethnobotany and conservation: A synthesis. Bot Rev 83: 152-194.

31. Ornduff $R$ (1985) Male-biased sex ratios in the cycad Macrozamis riedlei (Zamiaceae). Bull Torrey Bot Club 112: 393-397.

32. Skelley P, Xu G, Tang W, Lindström AJ, Marler T, Khuraijam JS, et al.
(2017) Review of Cycadophila Xu, Tang \& Skelley (Coleoptera: Erotylidae: Pharaxonothinae) inhabiting Cycas (Cycadaceae) in Asia, with descriptions of a new subgenus and thirteen new species. Zootaxa 4267: 1-63.

33. Terry I, Roe M, Tang W, Marler TE (2009) Cone insects and putative pollen vectors of the endangered cycad, Cycas micronesica. Micronesica 41: 83-99.

34. Terry I, Tang W, Marler TE (2012) Pollination systems of island cycads: Predictions based on island biogeography. Memoirs New York Botanical Garden 106: 102-132.

35. Griffith MP, Calonje M, Meerow AW, Tut F, Kramer AT, et al. (2015) Can a botanic garden cycad collection capture the genetic diversity in a wild population? Int J Plant Sci 176: 1-10.

36. Kashimshetty Y, Pelikan S, Rogstad SH (2017) Effective seed harvesting strategies for the ex situ genetic diversity conservation of rare tropical tree populations. Biodiversity and Conservation 26: 1311-1331.

37. Cibrian-Jaramillo A, Daly AC, Brenner E, DeSalle R, Marler TE (2010) When North and South don't mix: genetic connectivity of a recently endangered oceanic cycad, Cycas micronesica, in Guam using EST-microsatellites. Molecular Ecology 19: 2364-2379. 